\title{
PENINGKATAN HASIL BELAJAR SISWA MELALUI MODEL PEMBELAJARAN DIRECT INSTRUCTION (DI) PADA PEMBELAJARAN FISIKA
}

\author{
Fatimah $^{*}$ \\ Gruru SMA Negeri 1 Dewantara \\ *Korenspondensi: fatimahkaswandi@gmail.com
}

\begin{abstract}
ABSTRAK: Penelitian ini bertujuan untuk mengetahui apakah model Direct Instruction ( DI ) dapat meningkatkan hasil belajar siwa pada pembelajaran fisika. Sumber data dalam penelitian ini adalah seluruh siswa kelas kelas XI MIPA 1 SMA Negeri 1 Dewantara. Jenis penelitian yang digunakan adalah Penelitian Tindakan Kelas. Penelitian ini dilaksanakan dalam 2 siklus yang di dasarkan pada pokok bahasan Listrik Dinamis dengan pembelajaran DI. Siklus pertama berlangsung selama 2 x 45 menit, siklus kedua selama 2 x 45 menit. Prosedur PTK ini mengikuti langkah-langkah PTK yang terdiri dari beberapa tahap diantaranya yaitu tahap planning (rencana, implementing (tindakan), observing (observasi), dan reflecting (refleksi) yang kemudian diikuti dengan perencanaan ulang pada siklus kedua. Setelah melaksanakan siklus 1 dan siklus 2 hasil belajar siswa menunjukkan adanya peningkatan hal ini dapat dilihat dari ketuntasan hasil belajar siswa pada siklus 1 sebesar $31 \%$ dimana nilai tertinggi nya 88 dan nilai terendah 25 meningkat pada siklus 2 menjadi presentase ketuntasan hasil belajar siswa sebesar $81 \%$ dimana nilai tertingginya 90 dan nilai terendahnya 40 .
\end{abstract}

Kata Kunci: Direct Instructtion, Hasil belajar, Fisika

\section{THE IMPROVEMENT RESULT OF STUDENTS'S LEARNING THROUGH DIRECT INSTRUCTION (DI) LEARNING MODEL IN PHYSICS LEARNING}

Abstract: This research aims to determine whether the Direct Instruction (DI) model can improve students's result of learning in physics learning. The sources of data in this research is the entire students of class XI MIPA 1 SMA Negeri 1 Dewantara . The type of this research is the Classroom Action Research. This research is conducted in 2 cycles which are based on the subject of Dynamic Electricity with DI learning. The first cycle lasts for 2 x 45 minutes, the second cycle for $2 \times 45$ min. PTK Procedure is to follow the PTK step by step that consists of several phases which are stage planning, implementing, observing, and reflecting which then followed by planning repeated in the second cycles. After implementing the first cycle and second cycle the students's result of learning showed their improvement this can be seen from the students for completed learning in cycle 1 by $31 \%$ where the highest score was 88 and the lowest score was 25 and increased in cycle 2 by percentage of students for completed learning at $81 \%$, where the highest value is 90 and the lowest value is 40 .

Key words: Direct Instruction, Result of learning, Physics

\section{PENDAHULUAN}

Pada dasarnya pendidikan merupakan salah satu hal penting dan menjadi dasar awal manusia untuk menjadi lebih dewasa, baik dan bermanfaat. Karena melalui pendidikan, orang mampu membedakan mana yang harus dikerjakan, mana yang harus diberikan, dan mana yang 
harus ditinggalkan hanya dengan pendidikan seseorang mampu memberikan kebaikan mengelola organisasi dan dunia. Hanya dengan pendidikan rumah sakit mampu berdiri dengan baik dan memberikan pelayanan. Dengan ilmu juga, bagaimana keluarga mampu mengatur keluarganya dan seterusnya. Dengan demikian, pentingnya orang berilmu dan mengamalkannya atau orang berpendidikan. Pantaslah bagaimana ketika Nabi Sulaiman ditawarkan oleh Allah antara harta dan ilmu, ternyata beliau memilih ilmu. Kemudian, Allah menurunkan wahyu yang pertama kepada Nabi Muhammad SAW di Gua Hira (Jabal Nur) ternyata juga ilmu, yaitu perintah membaca yang diabadikan dalam QS Al - A'laq (96) Rasululullah juga mengabadikan pentingnya pendidikan sebagaimana dalam hadistnya yaitu:

"Bahwa kalu kamu ingin bahagia di dunia maka dengan ilmu, dan jika ingin bahgia di akhirat, maka dengan ilmu, dan jika ingin berbahgia keduanya, maka juga dengan ilmu dan ilmu hanya dapat diperoleh melalui pendidikan"

Demikian juga bagaimana ketika Rasululullah meninggalkan wasiat kepada keluarga dan umatnya? Ternyata, Rasulullah juga bukan meninggalkan harta, melainkan hanya meninggalkan dua buah kitab yang menjadi pusat ilmu pengetahuan yang dijadikan sandaran hidup dan penggalian ilmu pengetahuan sehingga meskipun digali dari berbagi disiplin, ilmu tiada kering, termasuk ilmu manajemen pendidikan. Melaluinya pula, ilmu mampu menjadikan kebahagiaan hidup manusia di dunia dan akhirat. Ilmu peninggalan Rasulullah SAW. tersebut adalah Al- Qur'an dan Hadis.

SMA Negeri 1 Dewantara merupakan salah satu dari beberapa Sekolah Menegah Atas yang ada di Kabupaten Dewantara yang termasuk kualifikasi sekolah standar nasional. Sebagai sekolah standar nasional SMA Negeri 1 Dewantara senantiasa selalu berupaya meningkatkan delapan standar nasional pendidikan termasuk diantaranya adalah peningkatan profesionalisme guru sebagai ujung tombak pembelajaran dan penigkatan prestasi belajar peserta didik tentunya

Upaya peningkatan profesional guru dilakukan melalui berbagai pelatihan yang dapat mendukung tugas guru sebagai agen pembelajaran dikelas. Sedang untuk meningkatkan prestasi belajar siswa telah diupayakan pemenuhan kebutuhan buku teks atau buku pembelajaran untuk peserta didik sebagai sumber belajar serta berbagai fasilitas penunjang yang lain. Berbagai langkah telah dilakukan oleh sekolah SMA N 1 Dewantara hanya semata mata agar proses pembelajaran dapat berjalan efektif dengan hasil yang sesuai dengan harapan yaitu adanya peningkatan profesional guru sebagai agen pembelajaran dan adanya peningkatan prestasi belajar siswa. Untuk terciptanya proses pembelajaran yang efektif dengan hasil yang baik, guru merupakan kata kunci utama yang dapat menjadi ujung tombak adanya peningkatan prestasi belajar siswa.

Guru pada dasarnya selalu berusaha melaksanakan tugasnya sebagai seorang pembelajaran sebaik baiknya, agar tujuan pembelajaran dapat tercapai sebagaimana yang telah direncanakan dalam rencana pelaksanaan pembelajaran. Sebagai agen pembelajaran guru memiliki kemampuan menerapkan berbagai strategi, model pendekatan dan metode pembelajaran dalam melaksanakan proses pembelajaran di kelas agar dapat membawa peserta didik menguasahi kompetensi dasar tertentu sesuai dengan karakteristik materi pembelajaran atau dengan kata lain prestasi belajar peserta didik ada peningkatan kiranya. Prestasi belajar peserta didik dikatakan meningkat apabila setiap dilakukanya penilaian oleh guru, peserta didik mampu memperolah hasil atau nilai akademis sekurang kurangnya sama dengan kriteria ketuntasan minimal (KKM) yang telah ditetapkan setiap mata pelajaran serta terjadi perubahan sikap atau perilaku dan peningkatan psikomotor pada diri peserta didik sesuai dengan karakter. Penulis adalah salah satu guru Fisika di SMA Negeri 1 Dewantara yang diberi tugas mengajar mata pelajaran Fisika di kelas XI IPA 1. pada Saat melaksanakan tugas pembelajaran dikelas XI IPA 1. Tentang materi pembelajaran Kinematika dengan analisis Vektor dengan menggunakan 
model pembelajaran langsung (Direct Instruction atau di singkat dengan DI) melalui diskusi kelompok dan informasi. Diakhir proses pembelajaran penulis memiliki harapan semua peserta didik kelas XI IPA 1 dapat mencapai KKM yang telah di tetapkan yaitu 77 Namun setelah penulis melaksanakan penilaian / evaluasi terhadap peserta didik melalui ulangan harian, ternyata realita di lapangan menunjukan bahwa prestasi yang dicapai kelas XI IPA 1 belum sesuai dengan harapan sebagaimana ketuntasan belajar dikelas parallel yang lain. Hal ini dibuktikan atas dasar hasil ulangan harian dikelas XI IPA 1, dari 26 siswa hanya 8 siswa yang mampu memenuhi kriteria ketuntasan minimal (KKM).

Hasil ini menunjukan adanya suatu masalah yang harus diselesaikan yaitu mengapa banyak siswa kelas XI IPA 1 yang memiliki hasil belajar belum sesuai dengan KKM khusus materi kinematika dengan analisis vector bahkan dapat dikatakan masih sangat minin atau rendah. Rendahnya prestasi belajar Fisika di kelas XI IPA 1 bila dibandingkan dengan prestasi belajar kelas parallel lainnya merupakan permasalahan yang harus segera mendapatkan pemecahan. Atas dasar inilah maka penulis mengadakan penelitian tindakan kelas (PTK) yang khusus penulis fokuskan untuk perbaikan pemebelajaran dikelas XI IPA 1, adapun Upaya yang penulis lakukan untuk mengatasi masalah rendahnya prestasi belajar Fisika kelas XI IPA 1 adalah melaksanakan proses pembelajaran Direct Instruction (DI) Melalui diskusi kelompok dan informasi dengan harapan prestasi belajar Fisika peserta didik kelas XI IPA 1 SMA Negeri 1 Dewantara dapat meningkat kiranya.Berdasarkan latar belakang masalah yang telah diuraikan di atas penulis mencoba mengidentifikasi berbagai masalah saat pembelajaran Fisika berlangsung, apa yang menyebabkan rendahnya prestasi belajar Fisika peserta didik Kelas XI IPA 1. Adapun hasil identifikasi masalah yang penulis dapatkan saat proses pembelajaran Fisika berlangsung dikelas XI IPA 1 adalah sebagai berikut: mengapa Hasil belajar Fisika relatif rendah, apakah informasi yang disampaikan oleh guru kurang dimengerti oleh pesertadidik ataukah model pembelajaran yang dilaksanakan selama ini kurang menarik bagi peserta didik.

Faktor apa sajakah yang menyebabkan hasil belajar Fisika relative rendah. Apa yang harus dilakukan guru agar hasil belajar Fisika dapat meningkat kiranya, apakah dengan menerapkan model pembelajaran Direct Instruction (DI) dapat meningkatkan Kemampuan siswa dalam belajar fisika.

Dalam penelitian tindakan kelas ini penulis memberikan batasan masalah yang terfokus pada peningkatan Hasil belajar Fisika pada konsep Kinematika dengan analisis Vektor semester I tahun pelajaran 2015 / 2016 pada sekolah SMA Negeri 1 Dewantara Kabupaten Aceh Utara melalui model pembelajaran Direct Instruction (DI). Adapun Peningkatan Kemampuan belajar yang diinginkan dalam hal ini oleh penulis adalah sebagai berikut: adanya perubahan nilai hasil ulangan harian dari peserta didik yang lebih baik dari sebelumnya sehingga dapat terlihat dengan jelas adanya peningkatan nilai peserta didik, model pembelajaran Direct Instruction (DI) merupakan salah satu cara yang digunakan guru dalam menyajikan pembelajaran pada peserta didik tentang materi yang akan dipelajari yaitu Kinematika dengan analisis Vektor.

Berdasarkan latar belakang, identifikasi masalah dan batasan masalah yang telah penulis kemukakan diatas, maka akhirnya rumusan masalah dalam penelitian tindakan kelas ini adalh sebagai berikut: Apakah hasil belajar siswa melalui model pembelajaran Direct Instruction (DI) pada pembelajaran Fisika dapat meningkat?

Adapun yang menjadi anggapan dasar peneliti ini adalah: Pembelajaran Direct Intruction merupakan model pembelajaran yang sangat tepat untuk siswa kelas XII IPA 1 SMA Negeri 1 Dewantara, Siswa dianggap mampu apabila memperoleh nilai lebih dari atau sama dengan 77 batas tuntas atau kkm untuk materi Kinematika dengan analisis Vektor. 
Berdasarkan anggapan dasar di atas maka dapat dirumuskan hipotesis penelitian ini adalah terdapat peningkatan hasil belajar siswa melalui model Direct Instruction (DI) pada pembelajaran Fisika.

Untuk menghindari kesalahpahaman terhadap judul penelitian ini maka perlu adanya batasan istilah sebagai berikut: model pembelajaran langsung (Direct Intruction) adalah salah satu model pembelajaran yang dapat membantu siswa memperoleh keterampilan dasar dan informasi yang dilakukan secara bertahap, dan dapat diterapkan dalam bidang studi yang beriorentasi pada penampilan dan kinerja seperti menulis, membaca bahasa inggris, musik, pendidikan jasmani.

Hasil belajar adalah penguasaan pengetahuan atau keterampilan yang dikembangkan oleh mata pelajaran, biasanya ditunjukkan dengan nilai tes atau angka nilai yang diberikan oleh guru.Hasil belajar adalah hasil pencapaian maksimal menurut kemampuan anak pada waktu tertentu terhadap sesuatu yang dikerjakan, dipelajari, difahami dan diterapkan.Semua pelaku pendidikan (siswa, orang tua dan guru) pasti menginginkan tercapainya sebuah prestasi belajar yang tinggi, karena prestasi belajar yang tinggi merupakan salah satu indikator keberhasilan proses belajar

Fisika berasal dari kata Yunani yang berarti alam. Fisika adalah ilmu pengetahuan yang mempelajari gejala-gejala alam dan interaksi gejala-gejala alam itu .Didalam fisika kita mempelajari gejala-gejala alam,baik yang terjadi pada benda yang dapat kita amati (makro ) maupun benda-benda yang tidak dapat kita amati langsung ( mikro ) adapun contoh gejala alam yang bersifat makro adalah gerakan planet,gerakan yang dilakukan manusia,kecepatan ,percepatan dan lainnya.sedangkan contoh gejala alam yang bersifat mikro adalah lompatan electron,atom dan radiasi serta hantaran listrik (Kanginan, $1996: 1$ )

Kinematika adalah ilmu yang mempelajari tentang gerak benda tampa penyebab benda bergerak sedangkan analisis adalah pemeriksaan maka pengertian vektor adalah besaran yang mempunyai nilai dan arah. Contoh dari besaran ini misalnya perpindahan, kecepatan, percepatan, gaya, dan sebagainya

Fisika adalah ilmu pengetahuan berbasis eksperimen. Dalam melakukan eksperimen kita memerlukan pengukuran - pengukuran biasanya untuk menggambarkan hasil pengukuran kita menggunakan angka-angka setiap ukuran yang kita gunakan untuk menggambarkan gejala fisika secara kuantitatif disebut besaran (Supiyanto, 2006: 2). Fisika adalah salah satu cabang ilmu pengetahuan yang banyak sekali melakukan pengukuran, seperti mengukur panjang, massa, gaya dan lain-lain.

Pengukuran dalam fisika erat hubungannya dengan besaran-besaran tersebut. Dalam fisika definisi besaran adalah segala sesuatu yang mempunyai nilai dan dapat dinyatakan dengan angka (Kamajaya, dan Djatirman, 2000: 1).

Proses adalah berubahnya sesuatu menjadi sesuatu yang lain. fokus evaluasi pada proses adalah pemantauan sehingga dapat ditemukan informasi tentang rancangan dan proses pelaksanaan yang mendukung tercapainya tujuan (Raharjo, 2003: 32). Proses belajar mengajar yang tinggi menekankan pada pemberdayaan peserta didik. PBM lebih menekankan pada belajar hidup bersama, dan belajar menjadi diri sendiri

Dalam proses belajar mengajar guru memiliki tiga tugas utama yang harus dikembangkan yaitu: 1. Mendidik untuk mengembangkan sikap atau kepribadian siswa, mengajar untuk mengembangkan kemampuan berpikir dan 3 melatih untuk mengembangkan keterampilan siswa, Ketiga tugas diatas harus dibangun sendiri oleh guru sebagai pelaku proses pembelajaran di dalam kelas jadi guru harus selalu berupaya menemukan pengalaman atau pengetahuan untuk di praktikan di kelas (Yasin, 2002: 20) 
Belajar dapat diartikan sebagai proses perubahan tingkah laku atau kecakapan manusia sehingga lebih mampu berinteraksi dengan lingkungan. Banyak pembelajar atau siswa yang memaksa diri belajar fisika sampai pagi hanya karena keesokan harinya harus menghadapi ujian harian tidak sedikit siswa atau pembelajar yang merasa takut atau gugub ketika guru mengadakan ulangan karena siswa tidak siap, siswa tidak perlu panik, karena mareka hanya perlu mengubah kebiasaan belajar menjadi lebih baik.

Belajar adalah berubah, dalam hal ini yang dimaksud belajar adalah usaha mengubah jiwa manusia baik pengetahuan, keterampilan dan sikap. Kita harus menjahukan pikiran pembelajar atau siswa jangan sampai terserang penyakit malas khususnya pada pelajaran fisika.karena penyakit ini sangatlah berbahaya setiap jiwa yang malas pastilah timbul di benak para siswa bahwa belajar itu dianggap monoton dan membosakan.seperti menghapal rumus ,menyelesaikan perhitungan dan mengingat konsep itu saja yang dilakukan dari hari kehari sehingga siswa merasa jenuh.apalagi sebagian besar pembelajar ( siswa ) memandang belajar merupakan hal yang menakutkan,belajar dianggap tidak menawarkan apapun selain rasa bosan , lelah dan malas tentulah pandangan seperti ini sangatlah keliru namun itulah kenyataannya,siapa yang harus disalahkan pernahkah kita sebagai guru merenungkanya jika pernah tentulah kita akan menemukan jawaban yang tepat dan benar ,maka jawaban yang paling tepat adalah guru karena guru pelaku utama dalam pembelajaran ada banyak kemungkinan diantaranya ; mungkin karena strategi kita sebagai pengajar yang kurang tepat,semangat belajar kita yang sudah mulai luntur atau karena stamina kita tidak memungkinkan akhirnya siswa dan guru di kalahkan oeh virus bosan dan kuman malas.( Pabichara, 2007: 4)

Kita sebagai umat islam yaitu Al-Qur"an dan Hadis nabi besar Muhammad SAW, saya selalu yakin akan satu hal yaitu: "Sesungguhnya sesudah kesulitan itu pasti ada kemudahan maka dari itu kita sebagai guru haruslah merencanakan proses belajar mengajar dengan baik dan menyenangkan artinya dalam mengajar kita harus punya seribu cara sehingga fisika itu menjadi mata pelajaran yang di sukai siswa kiranya tentunya kita harus mengajar dengan baik dan ikhlas

Mengajar merupakan suatu usaha atau perbuatan yang memerlukan tanggungjawab moral yang paling besar mengajar pada dasarnya adalah: membantu dan melanyani serta membimbing siswa untuk memperoleh ilmu yang berguna dan bermamfaat Proses belajar mengajar merupakan suatu inti dari proses pendidikan secara keseluruhan dengan guru sebagai pelaku utama atau dengan kata lain proses belajar mengajar. Pada saat belajar mengajar kita selalu mengunakan otak untuk mengingat, Otak merupakan senjata andalan dalam setiap pembelajaran. Otak juga digunakan untuk mengungkapkan gambaran kecerdasan atau kebodohan seseorang, dikemukakan oleh Pabichara Krisna (2007: 74).

Dalam proses pembelajaran, media yang digunakan guru harus sesuai dengan tujuan agar mampu merangsang dan menumbuhkan minat siswa dalam belajar walaupun sambil bermain. Akhir kata: Terus belajar dan belajar, tidak pernah putus asa, tidak pernah merasa gagal dan selalu optimis. Yakin akan datangnya pertolongan Allah, rajin belajar, tidak minder dan selalu berbaik sangka. Dari pendapat tersebut dapat disimpulkan bahwa kegiatan belajar merupakan kegiatan aktif siswa untuk membangun makna atau pemahaman terhadap suatu obyek atau suatu peristiwa. Sedangkan kegiatan mengajar merupakan upaya kegiatan menciptakan suasana yang mendorong inisiatif, motivasi dan tanggung jawab pada siswa untuk selalu menerapkan seluruh potensi diri dalam membangun gagasan melalui kegiatan belajar sepanjang hayat.

Proses belajar mengajar fisika meliputi seluruh kegiatan yang dilakukan oleh seorang guru mulai dari perencanaan,pelaksanaan,penilaian dan tindak lanjut yang berlangsung untuk 
mencapai tujuan dari pembelajaran fisika Pada hakikatnya dalam kehidupan manusia setiap saat terjadi proses belajar mengajar dari manusia kecil hingga dewasa seperti kata pepatah belajar dari ayunan hingga kelianglahat artinya selama kita hidup kita akan terus melaksanakan proses belajar dan mengajar.karena bila ada proses belajar tentulah akan ada juga proses mengajar yang akhirnya akan diperoleh suatu hasil yang di sebut prestasi belajar atau hasil dari belajar

Pada model pembelajaran langsung terdapat 5 tahapan penting. Guru mengawali pembelajaran dengan penejalsan tentang tujuan dan latar belakang pembelajaran serta menyiapkan siswa untuk menerima penjelasan guru. Tahapan selanjutnya di ikuti oleh persentase materi ajar yang diajarkan atau demontrasi tentang keterampilan tertentu. Pelajaran ini termasuk juga pemberian umpan baik terhadap keberhasilan siswa. Pada tahap penelitian dan pemberian umpan balik tersebut, guru perlu selalu mencoba memberikan kesempatan pada siswa untuk menerapkan pengetahuan dan keterampilan yang dipelajari ke dalam situasi kehidupan nyata. Fase-fase tersebut dapat disajikan dalam tabel sebagai berikut.

Tabel 1. Sintaks Model Pembelajaran Langsung

\begin{tabular}{|l|l|l|}
\hline No & Fase & Peran Guru \\
\hline 1. & $\begin{array}{l}\text { Menyampaikan tujuan dan } \\
\text { mempersiapkan siswa }\end{array}$ & $\begin{array}{l}\text { Guru menjelaskan tujuan, informasi, latar } \\
\text { belakang pelajaran, pentingnya pelajaran, } \\
\text { mempersiapkan siswa untuk belajar }\end{array}$ \\
\hline 2. & $\begin{array}{l}\text { Mendemonstrasikan } \\
\text { pengetahuan dan keterampilan }\end{array}$ & $\begin{array}{l}\text { Guru mendemontrasikan keterampilan } \\
\text { dengan benar, atau menyajikan informasi } \\
\text { tahap demi tahap. }\end{array}$ \\
\hline 3. & Membimbing pelatihan & $\begin{array}{l}\text { Guru merencanakan dan memberi } \\
\text { bimbingan pelatihan awal }\end{array}$ \\
\hline 4. & $\begin{array}{l}\text { Mengecek pemahaman dan } \\
\text { memberikan umpan balik }\end{array}$ & $\begin{array}{l}\text { Mengecek apakah siswa telah berhasil } \\
\text { melakukannya dengan baik, memberikan } \\
\text { umpan balik }\end{array}$ \\
\hline 5. & $\begin{array}{l}\text { Memberikan kesempatan untuk } \\
\text { pelatihan lanjutan penerapan }\end{array}$ & $\begin{array}{l}\text { Guru memberi kesempatan kepada siswa } \\
\text { untuk melakukan pelatihan lanjutan } \\
\text { dengan perhatian khusus pada penerapan } \\
\text { kepada situasi lebih kompleks dan } \\
\text { kehidupan sehari-hari }\end{array}$ \\
\hline
\end{tabular}

Sumer: Trianto (2010:43)

Di dalam istilah hasil belajar, terdapat dua unsur di dalamnya, yaitu unsur hasil dan unsur belajar. Hasil merupakan suatu hasil yang telah dicapai pelajar dalam kegiatan belajarnya (dari yang telah dilakukan, dikerjakan, dan sebagainya) sebagaimana dijelaskan dalam kamus besar bahasa Indonesia (1995:787). Dari pengertian ini, maka hasil belajar adalah penguasaan pengetahuan atau keterampilan yang dikembangkan oleh mata pelajaran, lajimnya ditunjukkan dengan nilai tes atau angka nilai yang diberikan oleh guru.

Belajar itu sebagai suatu proses perubahan tingkah laku, atau memaknai sesuatu yang diperoleh. Akan tetapi apabila kita bicara tentang hasil belajar, maka hal itu merupakan hasil yang telah dicapai oleh siswa.

Nawawi (1981:100) mengemukakan pengertian hasil adalah sebagai berikut: keberhasilan murid dalam mempelajari materi pelajaran di sekolah yang dinyatakan dalam bentuk nilai atau 
skor dari hasil tes mengenai sejumlah pelajaran tertentu. Menurut Nawawi (1981:127) berdasarkan hasil belajar dibagi menjadi tiga macam yaitu:

1) Hasil belajar yang berupa kemampuan keterampilan atau kecakapan di dalam melakukan atau mengerjakan suatu tugas, termasuk di dalamnya keterampilan menggunakan alat.

2) Hasil belajar yang berupa kemampuan penguasaan ilmu pengetahuan tentang apa yang dikerjakan.

3) Hasil belajar yang berupa perubahan sikap dan tingkah laku.

\section{METODE}

Penelitian ini merupakan Penelitian Tindakan Kelas (PTK), Penelitian ini dilaksanakan di SMA Negeri 1 Dewantara yang terletak di Desa paloh lada yang dipimpin oleh seorang Kepala Sekolah yaitu Dra Zuraida Sekolah ini memiliki 27 ruang kelas dan yang menjadi Fokus Peneliti adalah kelas XI IPA 1 . Penelitian ini di mulai bulan juli 2015 sampai dengan bulan agustus 2015. Subyek penelitian ini adalah siswa kelas XI IPA 1 dengan jumlah siswanya adalah 26 orang siswa yang terdiri dari 7 siswa laki-laki dan 19 siswa perempuan . Penelitian ini dilakukan di SMA Negeri 1 dewantara. Tahun ajaran 2015 / 2016. Variabel yang harus di selidiki oleh peneliti yang bertindak sebagai guru adalah sebagai berikut: Meningkatkan hasil belajar siswa kelas XI IPA 1 dalam proses pembelajaran Fisika

Penelitian ini dilaksanakan dalam dua siklus yang di dasarkan pada pokok bahasan yang sesuai dengan kesepakatan siswa (pokok bahasan yang dianggap sulit).Siklus pertama berlangsung selama $2 \times 45$ menit dan siklus kedua selama $2 \times 45$ menit.Prosedur PTK ini mnegikuti prinsip-prinsip PTK, yaitu terdiri dari beberapa tahap diantaranya; tahap planning (rencana tindakan), implementing (tindakan), observing (observasi), dan reflecting (refleksi) yang kemudian diikuti dengan perencanaan ulang pada siklus kedua . Berikut gambar alur PTK:

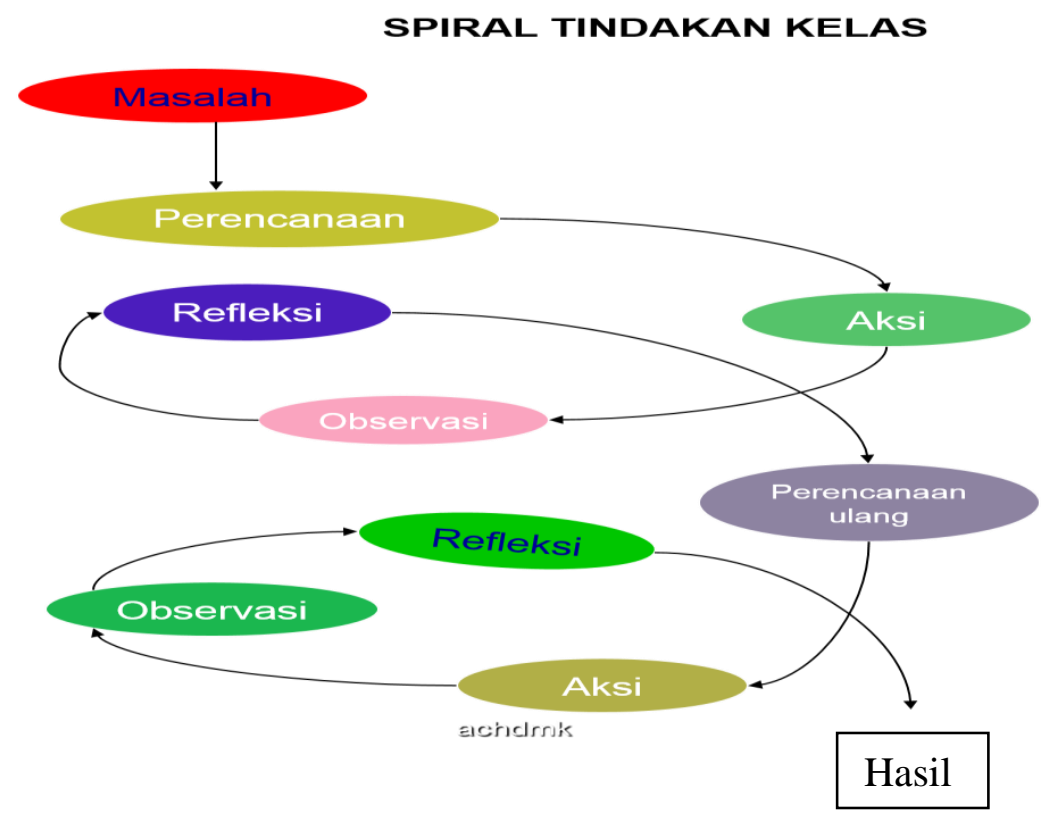




\section{Gambar 1: Alur PTK}

\section{HASIL DAN PEMBAHASAN}

Sebelum pelaksanaan tindakan kelas dilakukan, peneliti mengelompokkan siswa kelas XI IPA 1 SMA Negeri Krueng Geukueh menjadi 5 kelompok dengan masing-masing kelompok beranggotakan 5-6 orang, yang mana kelompok tersebut dibentuk secara heterogen, menurut tingkatan kemampuan yang di milikinya Pengelompokan siswa-siswa tersebut berdasarkan hasil tes awal atau tes kemampuan dasar tentang kinematika dengan analisis vektor yang mereka peroleh. Berdasarkan hasil tes awal tersebut, maka peneliti membuat criteria penilaian sebagai berikut:

a. Tingkat tinggi dengan nilai $80 \mathrm{ke}$ atas

b. Tingkat sedang denga nilai $77 \mathrm{~s} / \mathrm{d} 80$

c. Tingkat rendah dengan nilai dibawah 77 .

Ranking skor tes awal dan pembagian kelompok tiap tingkat dapat dilihat pada tabel berikut:

Tabel 2. Tingkat Kemampuan dasar siswa berdasarkan Tes Awal

\begin{tabular}{|c|c|c|c|}
\hline $\begin{array}{l}\text { Tingkat } \\
\text { Kemampuan }\end{array}$ & Nama siswa & Nilai & Kelompok \\
\hline \multirow{6}{*}{ Tinggi } & $\mathrm{AN}$ & 88 & I \\
\hline & $\mathrm{ZN}$ & 88 & II \\
\hline & $\mathrm{AS}$ & 85 & III \\
\hline & SAR & 84 & IV \\
\hline & SM & 84 & $\mathrm{~V}$ \\
\hline & RA & 81 & $\mathrm{I}$ \\
\hline \multirow{14}{*}{ Sedang } & CSW & 80 & II \\
\hline & $\mathrm{ZM}$ & 80 & III \\
\hline & FW & 80 & IV \\
\hline & LR & 78 & $\mathrm{~V}$ \\
\hline & $\mathrm{RM}$ & 78 & $\mathrm{I}$ \\
\hline & DM & 78 & II \\
\hline & MF & 78 & III \\
\hline & MAR & 78 & IV \\
\hline & SM & 78 & $\mathrm{~V}$ \\
\hline & $\mathrm{ZH}$ & 78 & $\mathrm{I}$ \\
\hline & $\mathrm{NF}$ & 78 & II \\
\hline & NS & 77 & III \\
\hline & HDU & 77 & IV \\
\hline & NS & 77 & V \\
\hline \multirow{6}{*}{ Rendah } & AY & 60 & I \\
\hline & FD & 60 & II \\
\hline & IE & 48 & III \\
\hline & RI & 42 & IV \\
\hline & MA & 40 & $\mathrm{~V}$ \\
\hline & SR & 25 & $\mathrm{I}$ \\
\hline
\end{tabular}


Berdasarkan tes awal yang telah dilaksanakan tersebut maka peneliti membentuk kelompok berdasarkan kriteria 1 orang berkemampuan tinggi, 2-3 orang berkemampuan sedang dan 1-2 orang berkemampuan rendah. Setelah semua anggota kelompok dibentuk, selanjutnya ditetapkan subjek wawancara yang terdiri dari 5 siswa yang telah mewakili tingkat kemampuan siswa.

\section{Data hasil belajar fisika dan pembahasanya Siklus I}

Kegiatan yang dilakukan pada siklus I meliputi tahap perencanaan, pelaksanaan tindakan, pengamatan terhadap pelaksanaan tindakan, dan refleksi.

Hasil belajar siswa yang telah di evaluasi oleh guru dapat dilihat pada tabel dibawah ini:

Tabel 3. Hasil Tes Akhir Siklus I tentang Kinematika dengan Analisis Vektor

\begin{tabular}{|l|l|l|l|l|}
\hline No & Nama Siswa & KKM & Nilai & Keterangan \\
\hline 1 & AN & 77 & 88 & Tuntas \\
\hline 2 & AS & 77 & 66 & Tidak Tuntas \\
\hline 3 & AY & 77 & 60 & Tidak Tuntas \\
\hline 4 & CSW & 77 & 67 & Tidak Tuntas \\
\hline 5 & DM & 77 & 68 & Tidak Tuntas \\
\hline 6 & FW & 77 & 80 & Tuntas \\
\hline 7 & FB & 77 & 60 & Tidak Tuntas \\
\hline 8 & HDU & 77 & 70 & Tidak Tuntas \\
\hline 9 & IE & 77 & 48 & Tidak Tuntas \\
\hline 10 & LR & 77 & 71 & Tidak Tuntas \\
\hline 11 & MF & 77 & 73 & Tidak Tuntas \\
\hline 12 & MAR & 77 & 68 & Tidak Tuntas \\
\hline 13 & MA & 77 & 40 & Tidak Tuntas \\
\hline 14 & NS & 77 & 62 & Tidak Tuntas \\
\hline 15 & NF & 77 & 60 & Tidak Tuntas \\
\hline 16 & NSL & 77 & 73 & Tidak Tuntas \\
\hline 17 & RA & 77 & 56 & Tidak Tuntas \\
\hline 18 & RI & 77 & 42 & Tidak Tuntas \\
\hline 19 & RM & 77 & 80 & Tuntas \\
\hline 20 & SM & 77 & 84 & Tuntas \\
\hline 21 & SMD & 77 & 80 & Tuntas \\
\hline 22 & SAR & 77 & 84 & Tuntas \\
\hline 23 & SR & 77 & 25 & Tidak Tuntas \\
\hline 24 & ZM & 77 & 81 & Tuntas \\
\hline 25 & ZN & 77 & 87 & Tuntas \\
\hline 26 & ZH & 77 & 72 & Tidak Tuntas \\
\hline & & & & \\
\hline
\end{tabular}

Dari tabel 3. terlihat dengan jelas bahwa perolehan nilai tes hasil belajar siswa pada Siklus 1 masih sangat rendah karena hanya 8 orang siswa sajalah yang baru mencapai ketuntasan belajar secara individu karena memperoleh hasil belajar diatas 77 (sesuai dengan KKM pada mata pelajaran Fisika untuk kelas XI IPA 1) dari 26 siswa. Maka diperoleh presentase ketuntasan hasil belajar siswa sebesar 31\% dimana nilai tertinggi nya 88 dan nilai terendah 25, Persentase tersebut masih terlalu rendah dan sangatlah jauh dari kriteria yang telah ditentukan oleh peneliti yaitu paling sedikit $77 \%$ 
Refleksi dilakukan untuk menentukan apakah tindakan tindakan I harus diulangi atau sudah berhasil, berdasarkan hasil pengamatan peneliti selama pelaksanaan tindakan I, pada kegiatan belajar kelompok siswa sudah bisa bekerjasama dengan baik dan juga dapat menyelesaikan tugas-tugas yang diberikan guru dengan baik pula tapi belum benar hal ini mungkin saja di sebabkan oleh soal latihan yang di berikan guru terlalu sulit atau susah di pahami siswa atau soal yang di berikan itu belum sesuai dengan tujuan pembelajaran maka untuk siklus 2 nanti di harapkan guru dapat membuat soal latihan atau tes yang sesuai dengan tujuan pembelajaran .

Hasil tes akhir tindakan I menunjukkan 18 orang siswa yang belum mencapai ketuntasan belajar secara individu karena memperoleh hasil belajar < 77 dan siswa yang memperoleh hasil belajar $\geq 77$ berjumlah 8 orang. Maka diperoleh presentase ketuntasan hasil belajar siswa sebesar $31 \%$, dimana presentase tersebut masih jauh dari kriteria penelitian yang telah ditentukan.

Data Hasil tes belajar fisika dan pembahasannya siklus 2

Hasil pemeriksaan siklus II ini dapat di lihat pada tabel 4 berikut ini:

Tabel 4. Hasil Tes Akhir Siklus II tentang Kinematika dengan Analisis Vektor

\begin{tabular}{|l|l|l|l|l|}
\hline No & Nama Siswa & KKM & Nilai & Keterangan \\
\hline 1 & AN & 77 & 90 & Tuntas \\
\hline 2 & AS & 77 & 76 & Tidak Tuntas \\
\hline 3 & AY & 77 & 80 & Tuntas \\
\hline 4 & CSW & 77 & 80 & Tuntas \\
\hline 5 & DM & 77 & 78 & Tuntas \\
\hline 6 & FW & 77 & 80 & Tuntas \\
\hline 7 & FD & 77 & 67 & Tidak Tuntas \\
\hline 8 & HDU & 77 & 77 & Tuntas \\
\hline 9 & IE & 77 & 58 & Tidak Tuntas \\
\hline 10 & LR & 77 & 80 & Tuntas \\
\hline 11 & MF & 77 & 78 & Tuntas \\
\hline 12 & MAR & 77 & 78 & Tuntas \\
\hline 13 & MA & 77 & 65 & Tidak Tuntas \\
\hline 14 & NS & 77 & 78 & Tuntas \\
\hline 15 & NF & 77 & 80 & Tuntas \\
\hline 16 & NSA & 77 & 78 & Tuntas \\
\hline 17 & RA & 77 & 81 & Tuntas \\
\hline 18 & RI & 77 & 77 & Tuntas \\
\hline 19 & RM & 77 & 80 & Tuntas \\
\hline 20 & SM & 77 & 84 & Tuntas \\
\hline 21 & SMD & 77 & 82 & Tuntas \\
\hline 22 & SAR & 77 & 86 & Tuntas \\
\hline 23 & SR & 77 & 40 & Tidak Tuntas \\
\hline 24 & ZM & 77 & 87 & Tuntas \\
\hline 25 & ZN & 77 & 90 & Tuntas \\
\hline 26 & ZH & 77 & 78 & Tuntas \\
\hline & & & & \\
\hline
\end{tabular}


Dari table 4 dapat terlihat dengan jelas hasil belajar siswa pada tindakan II hanya 5 orang siswa yang belum mencapai ketuntasan belajar secara individu karena memperoleh hasil belajar < 77 (sesuai dengan KKM pada mata pelajaran fisika kelas XI IPA 1) dari 26 siswa. Maka diperoleh presentase ketuntasan hasil belajar siswa sebesar $81 \%$ dimana nilai tertingginya 90 dan nilai terendahnya 40 persentase tersebut sudah sesuai dengan criteria penelitian yang telah ditentukan oleh peneliti yaitu minimal 77\%. Alhamdulillah penelitian ini berhasil karena kemampuan siswa sudah meningkat yaitu sudah mencapai $81 \%$. Maka sudah termasuk kedalam katagori tinggi sesuai dengan kriteria penilaian

\section{PENUTUP}

Hasil pembelajaran Siklus I terhadap kegiatan guru menurut pengamat mencapai $68 \%$ sementara terhadap kegiatan siswa menurut pengamat yaitu $67 \%$ Berarti guru dan siswa telah dapat melaksanakan kegiatan belajar dengan cukup. Namun, pada tindakan I belum mencapai keberhasilan karena jumlah presentase tes akhir $31 \%$ hanya 8 orang siswa yang tuntas, dengan perolehan nilai terendah 25 dan tertinggi 88. Berdasarkan hasil pelaksanaan siklus I maka diputuskan bahwa tindakan I harus diulang kembali dengan siklus II. Berdasarkan pengamatan yang dilakukan pada pelaksanaan Siklus II kegiatan guru menurut pengamat sudah mencapai 92 $\%$ sementara terhadap kegiatan siswa menurut pengamat yaitu $92 \%$, oleh karenanya siswa juga telah dapat melaksanakan kegiatan belajar dengan sangat baik, dan Siklus II telah mencapai keberhasilan dengan baik dan tuntas karena jumlah presentase tes akhir $81 \%$. Dimana hanya tinggal 5 orang siswa sajalah yang belum tuntas dengan nilai terendah 40 dan nilai tertinggi 90 . Hal ini membuktikan bahwa Penerapan model Direct Intruction dapat meningkatkan hasil belajar siswa pada pembelajaran Fisika khususnya pada materi kinematika dengan analisis vektor pada siswa kelas XI IPA 1 SMA Negeri 1 Dewantara.

\section{DAFTAR PUSTAKA}

Alberty (1998). Pilar-pilar utama pendidikan. Bandung: Penerbit Kolbu.

Balitbang Kemdikbud. (2006). Standar Operasional Proses Kurikulum KTSP. Jakarta: Kemdikbud.

Hamalik, O. (2009). Prosedur Pembelajaran. Jakarta: Departemen Pendidikan Nasional Direktorat Jenderal Pendidikan Dasar dan Menengah Direktorat Tenaga Kependidikan.

Hakim, A, Liliasari, Kadorohman, A. (2012). Student Concept Understanding of Natural Products Chemistry in Primary and Secondary Metabolites Using the Data Collecting Technique of Modified CRI. International Online Journal of Educational Sciences. 4(3): 544-553.

H.J. Gino (1998), Ciri-ciri pembelajaran sukses. Penerbit: IKIP Malang

Herbart, J. (2001). Konsep utama Pembelajaran Bandung. Penerbit: Kolbu.

Madya, S. (2011). Teori dan praktik penelitian tindakan (action research). Bandung: Alfabeta

Mathen, K. (1996). Fisika untuk SMA kelas XI IPA. Jakarta: Erlangga.

Pabichara krisna. (2007).12 Rahasia pembelajaran cemerlang. Bandung: Kolbu

Rohani, A. (2003). Sumber utama motivasi belajar. Bandung: Irama widya.

Sanjaya, W. (2006). Strategi Pembelajaran Berorientasi Proses. Jakarta: Kencana. 
Soedarso. (2004). Speed Learning untuk segala umur dan semua kalangan. Jakarta: CV Fauzan Inti Kreasi.

Subiyanto. (1990). Strategi belajar mengajar ilmu pengetahuan alam. Malang: IKIP Malang Suparman. (2007). Pendidikan IPA Sekolah Menengah. Jakarta: Studi Magister Pendidikan Matematika dan IPA UPI.

Sunardi. (2006). IPA Bilingual untuk SMP kelas IX semester 1 dan 2. Bandung. Yrama widya. Suharsono. (2014). Evaluasi Pendidikan. Jakarta: Bumi Aksara

Supiyanto. (2006). Fisika untuk SMA kelas IX Jakarta: Phibeta. 